В заключении следует отметить, что колористические способности как психологопедагогическая категория представляют собой одну из составляющих художественнотворческих способностей, развитие которых является сложным процессом, требующим определенных педагогических условий.

$$
* * *
$$

1. Ермолаева-Томина, Л.Б. Психология художественного творчества учебное пособие для вузов / Ермолаева-Томина Л.Б. - М.: Академический Проект, Культура, 2015. - 304 с.

2. Ивахнова, Л.А. Профессиональная деятельность учителя изобразительного искусства: учебное пособие. - 3-е изд., перераб. и доп. / Л.А. Ивахнова. - Омск: Изд-во ОмГПУ, 2013. - 116 с.

3. Рубинштейн, С.Л. Основы общей психологии: учеб. пособие для студентов высших учебных заведений / С.Л. Рубинштейн. - СПб.: Питер, 2007. - 713 с.

\title{
Кукса Д.А., Кукса П.В. \\ Некоторые учебно-познавательные трудности иностранных военнослужащих в процессе адаптации к обучению в российском вузе
}

РВВДКУ имени В.Ф. Маргелова

(Россия, Рязань)

doi: $10.18411 / l j-31-10-2017-46$

idsp: 000001:lj-31-10-2017-46

С каждым годом все больше иностранных граждан прибывает в Россию для получения высшего образования, и каждый иностранный обучаемый объективно проходит процесс адаптации. Термин «адаптация» в современной науке имеет ряд толкований.

Мы вслед за авторами «Большого психологического словаря» придерживаемся следующего определения термина: «адаптация - приспособление человека как личности к существованию в обществе в соответствии с требованиями этого общества и с собственными потребностями, мотивами и интересами».

Иностранные военнослужащие, обучающиеся на специальном факультете РВВДКУ, являются представителями различных этнических групп и культур, имеют национально-психологические и индивидуальные особенности, неодинаковый уровень базовой подготовки. Это обусловливает специфику процесса их обучения на всех этапах и определяет актуальность решения проблемы социально-психологической адаптации в целом и адаптации к учебному процессу в частности.

В процессе обучения иностранные военнослужащие испытывают учебнопознавательные трудности, вызванные различными факторами, в первую очередь:

- языковым барьером;

- преодолением различий в системах образования;

- организацией учебного процесса, отличного от формы и методов организации на родине;

- новыми требованиями в системе контроля знаний;

- формированием навыков самостоятельной работы;

- информационной насыщенностью учебных занятий;

- бытовыми условиями;

- погодными (климатическими) условиями;

- коммуникативными трудностями в процессе межличностного общения внутри многонациональной группы, общения с преподавателями и офицерами и т.д. 
Все это является естественной преградой для достижения целей обучения. Рассмотрим основные из отмеченных трудностей более подробно.

Одним из первых препятствий, с которым на пути к получению знаний сталкиваются иностранцы по приезде в Россию, является абсолютное незнание русского языка или недостаточный уровень владения им. Вследствие этого огромное значение приобретает так называемая языковая адаптация - процесс, направленный на преодоление языкового барьера. Бесспорным является тот факт, что лингвистическая проблема для иностранных обучаемых весьма актуальна и заслуживает самого пристального внимания как со стороны преподавателя РКИ, так и со стороны командиров.

Имеющиеся существенные различия в школьной подготовке учащихся в России и зарубежных странах обусловлены не только содержанием программ, но и качеством получаемых знаний, национальными особенностями.

Различия в национальных системах образования определяют необходимость корректировки в знаниях и умениях иностранных военнослужащих в соответствии с критериями сформированности предметно-речевых умений. Опыт обучения иностранных военнослужащих показывает, что для успешной учебной деятельности в российском вузе необходимо не только знание нейтральной и научной лексики русского языка и основных понятий по предметам общенаучного цикла, но и знание предметов общенаучного цикла на требуемом в российском вузе уровне.

Отдельно необходимо сказать о навыках самостоятельной работы. Вынуждены признать, что большинство из иностранных обучаемых не умеют самостоятельно приобретать знания и не имеют необходимых навыков самостоятельной работы. Однако эффективность обучения на иностранном для обучаемых языке во многом зависит от уровня их подготовленности, желания и способности к самостоятельной работе. Соответственно преподавателю и командиру следует создавать условия, в которых иностранный курсант будет учиться самостоятельно добывать знания.

В заключение настоящей статьи отметим сложность в адаптации иностранных военнослужащих, обусловленную новыми требованиями в системе контроля знаний. В процессе обучения иностранных военнослужащих непосредственными объектами контроля выступают умения, а знания становятся объектами проверки опосредованно, проявляясь в соответствующих умениях.

Кратко рассмотрев отдельные факторы, вызывающие определенные трудности в процессе обучения иностранных военнослужащих, отметим следующее. Вышеизложенное позволяет наметить перспективные направления дальнейшего исследования затронутой научной проблемы. На наш взгляд, необходимо тщательное изучение имеющихся (а также поиск новых) психолого-педагогических условий, направленных на успешную адаптацию иностранных военнослужащих в условиях обучения в российском вузе.

$$
* * *
$$

1. Большой психологический словарь. / Под ред. Б.Г. Мещерякова, акад. В.П. Зинченко - М.: ПраймЕВРОЗНАК, 2003.

2. Сурыгин, А.И. Педагогическое проектирование системы предвузовской подготовки иностранных студентов. - СПб: Златоуст, 2001.

3. Филимонова, Н. Ю. Особенности работы по привитию иностранным учащимся довузовского этапа навыков самостоятельной работы / Н. Ю. Филимонова, Н. В. Щукина // Материалы междунар. научно-практич. конф. -Днепропетровск, 2006. - Т. 13. - С. 29-31. 
4. Фильцова М. С. Объекты контроля при обучении русскому языку иностранных студентов-медиков (англоязычная форма образования) [Текст] // Аспекты и тенденции педагогической науки: материалы II Междунар. науч. конф. (г. Санкт-Петербург, июль 2017 г.). - СПб.: Свое издательство, 2017. -С. 8691.

5. Рогова, Н. В. Программа контроля в обучении немецкому языку. Методические рекомендации / Н. В. Рогова. - Иркутск, 2016. / https://infourok.ru/metodicheskie-rekomendacii-po-organizacii-kontrolya-vobuchenii-inostrannomu-yaziku-863906.html.

6. КиберЛенинка / https://cyberleninka.ru/article/n/rol-prepodavatelya-v-organizatsii-samostoyatelnoy-rabotyinostrannyh-studentov

\section{Куприянова А.Д. \\ Использование приемов мнемотехники в познавательно-речевом развитии дошкольников}

МУДО Дом детского творчества городского округа Павловский Посад Московской области

doi: $10.18411 / l j-31-10-2017-47$

idsp: 000001:lj-31-10-2017-47

\section{Аннотация}

В статье рассматривается вопрос о важности использования в познавательноречевом развитии дошкольников приемов мнемотехники.Раскрываются основные этапы работы с мнемотаблицами. Приводятся результаты применения этой методики в работе с детьми. Даются рекомендации по совершенствованию связной речи средствами мнемотехники.

Ключевые слова: мнемотехника, развитие речи, дошкольники.

К.Д. Ушинский писал: «Учите ребёнка каким-нибудь неизвестным ему пяти словам - он будет долго и напрасно мучиться, но свяжите двадцать таких слов с картинками, и он их усвоит на лету». Действительно, наглядность- ведущий дидактический принцип педагогики. Это важно помнить на всех этапах обучения детей, т.к. действия с предметами, их зрительное восприятие - это первый этап в развитии мышления ребенка.

Одной из главных задач воспитания и обучения детей дошкольного возраста является развитие речи. Владение родным языком - это не только умение правильно строить предложения, это умение рассказывать. Не просто называть предмет, но и описывать его.

Наглядность составляет основу в обучении рассказыванию детей дошкольного возраста. Поэтому на уроках развития речимы активно используем приемы мнемотехники.

Мнемотехника - это система методов, приемов, облегчающихзапоминание. Как это происходит?Для того чтобы запомнить какой-либо предмет, объект, человек в своём воображении создает некий зрительный образ. Эта взаимосвязь фиксируется в мозге, и при припоминании по одному из образов этой ассоциации мозг воспроизводит все ранее соединённые образы.

Всем известный коллаж, часто используемая в развитии речи схема составления рассказа, блоки-квадраты, предметно-схематические модели и пр. - все это и есть мнемотехника, или отдельные ее элементы. И основа всех приемов мнемотехники - это символизация. Символ облегчает запоминание слов, т.к. максимально приближен к речевому материалу.

Применение мнемотехники на занятиях с детьми старшего дошкольного возраста демонстрируют нам такие результаты, как увеличение объема памяти детей, приобретение навыков речевого моделирования. Представим себе, сколько ассоциаций, 